\title{
Cell Viability And Electrical Response of Breast Cancer Cell Treated In Aquoes Graphene Oxide Solution Deposition On Interdigitated Electrode
}

Muhammad M. Ramli

Universiti Malaysia Perlis

Anis Rosman

Universiti Malaysia Perlis

Nur Mazlan

Universiti Malaysia Perlis

Mohd Ahmad

Universiti Malaysia Perlis

Dewi Che Halin

Universiti Malaysia Perlis

Rafeezul Mohamed

Universiti Sains Malaysia

Nurul Osman ( $\nabla$ nurulhuda@upm.edu.my )

Universiti Putra Malaysia

Ali Reshak

University of Basrah

\section{Research Article}

Keywords: Graphene oxide (GO), Breast cancer cells (MCF7), Interdigitated electrode (IDE), Impedance, Resistance

Posted Date: August 4th, 2021

DOI: https://doi.org/10.21203/rs.3.rs-772026/v1

License: (c) (i) This work is licensed under a Creative Commons Attribution 4.0 International License. Read Full License 
Cell Viability and Electrical Response of Breast Cancer Cell Treated in Aquoes Graphene Oxide Solution Deposition on Interdigitated Electrode

Muhammad M. Ramli ${ }^{1,2}$; A. S. Rosman ${ }^{1}$; N. S. Mazlan ${ }^{1}$; M. F. Ahmad ${ }^{1,2}$; Dewi Suriyani Che Halin ${ }^{2}$, Rafeezul Mohamed $^{3}$; N. H. Osman ${ }^{*}$, Ali H. Reshak ${ }^{2,5,6}$

${ }^{1}$ Faculty of Electronic Engineering Technology, Universiti Malaysia Perlis (UniMAP), Perlis, Malaysia.

${ }^{2}$ Geopolymer \& Green Technology, Centre of Excellence (CEGeoGTech), Universiti Malaysia Perlis (UniMAP), Perlis, Malaysia.

${ }^{3}$ Advance Medical and Dental Institute, Universiti Sains Malaysia, Bertam, Jln Tun Hamdan Sheikh Tahir, 13200 Kepala Batas, Pulau Pinang, Malaysia.

${ }^{4}$ Applied Electromagnetic Lab 1, Department of Physics, Faculty of Science, Universiti Putra Malaysia, 43400 Serdang, Selangor, Malaysia.

${ }^{5}$ Physics Department, College of Science, University of Basrah, Basrah, Iraq

${ }^{6}$ Department of Instrumentation and Control Engineering, Faculty of Mechanical Engineering, CTU in Prague, Technicka 4, Prague 6166 07, Czech Republic

*Corresponding author: nurulhuda@upm.edu.my

Keywords: Graphene oxide (GO), Breast cancer cells (MCF7), Interdigitated electrode (IDE), Impedance, Resistance

\begin{abstract}
Breast cancer is one of the most reported cancers that can lead to death. Despite the advances in diagnosis and treatment procedures, the possibility of cancer recurrences is still high in many cases. With that in consideration, researchers from all over the world are showing interest in the unique features of Graphene oxide (GO), such as its excellent and versatile physicochemical properties, to explore further its potential and benefits towards breast cancer cell treatment. In this study, the cell viability and electrical response of GO, in terms of resistivity and impedance towards the breast cancer cells (MCF7) and normal breast cells (MCF10a), were investigated by varying the pH and concentration of GO. Firstly, the numbers of MCF7 and MCF10a were measured after being treated with GO for 24 and 48 hours. Next, the electrical responses of these cells were evaluated by using interdigitated electrodes (IDEs) gold electrodes that are connected to an E4980 $20 \mathrm{~Hz}-2 \mathrm{MHz}$ Precision LCR meter. Based on the results obtained, as the $\mathrm{pH}$ of GO increased from $\mathrm{pH} 5$ to $\mathrm{pH}$ 7, the number of viable MCF7 cells decreased while the number of viable MCF10a slightly increased after the incubation period of 48 hours. Similarly, the MCF7 also experienced higher cytotoxicity effects when treated with a GO concentration of more than $25 \mu \mathrm{g} / \mathrm{mL}$. The findings from the electrical characterization of the cells observed that the number of viable cells has corresponded to the impedance of the cells.
\end{abstract}


The electrical impedance of MCF7 decreased as the number of highly insulating viable cells membrane decreased, but in contrast, the electrical impedance of MCF10a increased as the number of highly insulating viable cells membrane increased. Hence, it can be deduced that the GO with higher $\mathrm{pH}$ and concentration impacts the MCF7 cancer cell line and MCF10a normal breast cell.

\section{Introduction}

The research on Graphene Oxide (GO) involved in medical applications has increased constantly throughout the years. The medical applications of GO include drug delivery (Barahuie et al., 2017; Kakran et al., 2011), tissue engineering (Fu et al., 2014), diagnostics and cancer treatment (Saeed et al., 2014b; Wu et al., 2015). The interactions between graphene-based nanomaterials with biological systems were previously discovered and explored (Barahuie et al., 2017; Chang et al., 2011; Gurunathan et al., 2013; Saeed et al., 2014a; Wu et al., 2015). However, there is still a lack of scientific support to determine the cytotoxicity effects caused by nanomaterials towards the normal and cancer cells. Hence, the crucial mechanisms of nanotoxicity due to the production of reactive oxygen species (ROS) were studied. When the ROS is overgenerated, it also creates oxidative stress that leads to the failure of the cells to maintain the normal physiological redox-regulated functions (Fu et al., 2014; Gurunathan et al., 2013). This consequently resulted in DNA damage, imbalance of cells signals and changes in cells cytotoxicity, apoptosis and cancer initiation. By comparing the normal and cancer cells, the ROS production and oxidative stresses are much higher in the cancer cells, making them more likely to undergo cell mutations, uncontrolled initiation of cellular proliferation, genetic instability and cell death. Therefore, the potential biomedicines to inhibit cancer include nanomaterials with chemical elements that can limit ROS production, as these have the potential to affect the cell viability of cancerous cells (Fu et al., 2014). According to (Zhang et al., 2016), even though graphene or graphenebased materials exhibited no effect on the mammalian cells at low concentrations, but the high graphene concentrations can affect the cell membrane integrity and cause cell death. These findings were similar and were also supported by (Saeed et al., 2014b) and (Wu et al., 2015). These studies suggested that the interactions between the high concentrations of graphene or graphene-based materials with the cells can degrade the cell membrane integrity, including the early-stage breast cancer cells (MCF7), pancreatic cancer cells (Panc-1) and invasive breast cancer cells (MDA-MB-231). 
Most of the commonly used biosensor are affinity-based. The affinity-based biosensor is referred to as an immobilized capture probe that binds to a particular target, therefore causes physiochemical changes that can be detected by a transducer. So that the cancer diagnosis can be made in a short time, the interdigitated electrode (IDEs) is one of the promising alternatives to assimilate the biosensors into a portable lab-on-chip device due to its ability to detect electrical changes in terms of impedance, resistance and capacitance (L. Wang et al., 2017). As stated by (Das et al., 2012), IDEs are usually used for various applications, especially as biological and chemical sensors, due to the low cost of production, easy to fabricate and high sensitivity.

The research by (Mamouni \& Yang, 2011) illustrated the principles of electrochemical impedance spectroscopy (EIS) measurement during the presence and absence of cells on the Bode impedance spectra. When there are no cells attached, the impedance will only be obtained from the resistance of the solution, $\mathrm{R}_{\mathrm{sol}}$ and the double-layer capacitance of the electrode, $\mathrm{C}_{\mathrm{dl}}$. However, when cells are deposited on the electrode surface, the newly formed circuit will include the impedance inclusive of the resistance of the dropped cells, $\mathrm{R}_{\text {cell }}$ and its capacitance, $\mathrm{C}_{\text {cell }}$ attached in parallel. The presence of cells also influences the changes of interface impedance, where the impedance is increased due to the highly insulating cells membranes that minimize the electrode area reached by the current. This eventually triggers the ionic environment changes around the electrode or solution interfaces, thus leading to the changes in $\mathrm{R}_{\mathrm{sol}}$ and $\mathrm{C}_{\mathrm{dl}}$ values. As stated in Equation 1 and Equation 2, the capacitance $\left(\mathrm{C}_{\text {cell }}\right)$ that contributes to the impedance (Z") is depending on the frequency (f), while the resistance $\left(\mathrm{R}_{\text {cell }}\right)$ that contributes to the impedance $\left(Z^{\prime}\right)$ is independent of the frequency. Hence, when the cells are attached at the electrode surface, the new impedance that consists of $R_{\text {cell }}$ and $\mathrm{C}_{\text {cell }}$ is generated, as shown in Equation 3.

$$
\begin{gathered}
Z^{\prime \prime}=\frac{1}{2 \pi f C_{c e l l}} \\
Z^{\prime}=R_{\text {cell }} \\
Z_{\text {cell }}=\sqrt{R_{\text {cell }}^{2}+\frac{1}{\left(2 \pi f C_{c e l l}\right)^{2}}}
\end{gathered}
$$

The new potential of GO in affecting cancerous cells is explored, as it has good surface functionality due to the oxidation process produced by using Hummer's method. Hence, GO was chosen to observe the treatment effects on MCF7 breast cancer cell and MCF10a normal breast based on the cell viability and after the incubation period of 
24 hours and 48 hours. In contrast to the previous research, the electrical responses and effects of MCF7 and MCF10a without using any redox solutions or biomarkers were studied to observe the direct interactions between the cells and GO. This is very important to fully understand the electrical responses between the cells, as it may be useful for developing an early breast cancer detection device.

\section{Experimental Details}

\subsection{Pre-oxidized graphite}

The first step of the study was to prepare the pre-oxidized graphite by following the protocol reported by (Muda et al., 2017). Firstly, a mixture was prepared by dissolving $3 \mathrm{~g}$ of graphite powder (NE Scientific, Malaysia), $2.5 \mathrm{~g}$ of potassium persulfate $\left(\mathrm{P}_{2} \mathrm{~S}_{2} \mathrm{O}_{8}\right)$ (Sigma Aldrich, Malaysia) and $2.5 \mathrm{~g}$ of phosphorus pentoxide $\left(\mathrm{P}_{2} \mathrm{O}_{5}\right)(\mathrm{Sigma}$ Aldrich, Malaysia) in $12 \mathrm{~mL}$ of sulfuric acid $\left(\mathrm{H}_{2} \mathrm{SO}_{4}\right)$ (Sigma Aldrich, Malaysia). Then, the solution mixture was kept in an oil bath for four and a half hours under the temperature of $80^{\circ} \mathrm{C}$. Next, the mixture was cooled to the ambient temperature before it was diluted further with $500 \mathrm{~mL}$ of DI water and left overnight. Finally, the mixture was filtered by using a $0.22 \mu \mathrm{m}$ PTFE membrane and was washed with DI water to achieve neutral conditions through removing the residual acid.

\subsection{Modified Hummer's method}

This section described Hummer's method to produce the aqueous GO with some modification. First, the preoxidized graphite was added into $120 \mathrm{~mL}$ of concentrated sulfuric acid pre-chilled to $0{ }^{\circ} \mathrm{C}$ and was kept incubated inside an ice bath. Then, $15 \mathrm{~g}$ of potassium permanganate $\left(\mathrm{KMnO}_{4}\right)($ Sigma Aldrich, Malaysia) was added gradually into the mixture to prevent extravagant heat. The mixture was stirred at $800 \mathrm{rpm}$ and must be kept under $20{ }^{\circ} \mathrm{C}$. Then, the mixture was stirred for 2 hours under $35^{\circ} \mathrm{C}$. After that, the mixture was added with $250 \mathrm{~mL}$ of DI water, before being placed into the ice bath for another 2 hours. Next, $700 \mathrm{~mL}$ of DI water was added, followed by $20 \mathrm{~mL}$ of $30 \%$ concentrated hydrogen peroxide $\left(\mathrm{H}_{2} \mathrm{O}_{2}\right)$ (Sigma Aldrich, Malaysia). This reaction generated an aggressive spark, while

the temperature rose to $70{ }^{\circ} \mathrm{C}$. Meanwhile, the mixture changed to a yellowish colour and indicated the production of well-oxidized graphite oxide. To remove the metal ions, the mixture was filtered and washed with 1:10 $\mathrm{HCl}$ solution, followed by $1 \mathrm{~L}$ of DI water to discard the residual acid. The resulted graphite oxide powder was dried at room temperature and weighed. Appropriate amount of GO powder was then dissolved with DI water to fix the 
concentration to $30 \mathrm{mg} / \mathrm{ml}$. Then, the GO solution was centrifuged under $6000 \mathrm{rpm}$ to obtain the desired $\mathrm{pH}$. The ultrasonication probe was used to exfoliate the GO sheets. Lastly, the GO was centrifuged at 4000 rpm for 20 minutes to further exfoliate the sheets.

\subsection{The production of different $\mathrm{pH}$ of GO}

After the oxidation process, the aqueous GO dispersion prepared by using the Hummers' method $(30 \mathrm{mg} / \mathrm{ml})$ was divided into three parts. These solutions were adjusted to the $\mathrm{pH}$ of 5, 6 and 7, respectively, by titration with 1:10 $\mathrm{HCl}$ and then washed with $1 \mathrm{~L}$ of DI water. These solutions were then centrifuged at $6000 \mathrm{rpm}$ for 30 minutes to obtain the concentrated graphite oxide with the desired $\mathrm{pH}$. To obtain the GO with the $\mathrm{pH}$ of 5 of GO, the solution was centrifuged for 16 times, 20 times to get the GO with the $\mathrm{pH}$ of 6 , and 24 times to get the GO with the $\mathrm{pH}$ of 7 .

\subsection{The production of different concentration of GO}

For this experiment, $5 \mathrm{mg} / \mathrm{ml}$ of GO with a pH of 5 was used to prepare a stock solution. Then, this GO stock solution was further diluted with DI water to produce 6 different concentrations; 2.5, 6.25, 12.5, 25, 50 and $100 \mu \mathrm{g} / \mathrm{ml}$, respectively.

\subsection{GO Characterization}

The GO was characterized by using Raman spectroscopy, X-ray Diffraction spectroscopy (XRD), Field Emission Scanning Electron Microscope (FESEM) and Energy-Dispersive X-ray spectroscopy (EDX) in order to validate and confirm the morphology and functional groups.

\subsection{Cell culture}

The breast cancer cell (MCF7) cultures were cultured in RPMI 1640 medium supplemented with $5 \%$ fetal bovine serum (FBS) and $1 \%$ penicillin-streptomycin and were incubated in a $90 \%$ humidified atmosphere with $5 \%$ $\mathrm{CO}_{2}$ under $37^{\circ} \mathrm{C}$. The normal breast cell (MCF10a) cultures were cultured in Dulbecco's Modified Eagle Medium (DMEM) supplemented with $10 \mu \mathrm{g} / \mathrm{mL}$ insulin, $20 \mathrm{ng} / \mathrm{mL}$ human epidermal growth factor (HEGF) hydrocortisone, 5\% horse serum and 5\% penicillin-streptomycin. The cells were also incubated in a $90 \%$ humidified atmosphere with $5 \% \mathrm{CO}_{2}$ under $37^{\circ} \mathrm{C}$. 


\subsection{Cell Viability}

MCF7 ( $1 \times 10^{4}$ cells $\left./ \mathrm{ml}\right)$ and MCF10a $\left(1 \times 10^{4}\right.$ cells $\left./ \mathrm{ml}\right)$ were seeded into 96-wells plates for 24 hours. Then, each well was added with either different $\mathrm{pH}$ ( $\mathrm{pH}$ of 5, 6 and 7) and concentrations (concentration of 2.5, 6.25, 12.5, $25,50$ and $100 \mu \mathrm{g} / \mathrm{ml})$ of GO, or with only medium. After that, the plates were incubated for an additional 24 and 48 hours. After incubation, the medium was discarded, and $10 \mu \mathrm{l}$ of PrestoBlue reagent (final volume $100 \mu \mathrm{l}$, freshly diluted in RPMI and DMEM immediately before treatment) was added and incubated for another 1 hour. The experiment for every condition of untreated and GO treated cells was conducted in triplicate for each 96-well plates and was repeated for three times. The results were measured with the excitation wavelength set at $590 \mathrm{~nm}$ for the fluorescent signal detection mode, by using the FLUOstar Omega microplate reader (BMG LABTECH, Australia). The percentage number of viable cells was calculated by using the Equation 5 to 8 as shown below.

Average media $=($ summation of three well plates for media only $) \div 3$

No. of cells $=($ Untreated cell or treated cell for each well $)-$ average media

Average untreated cells $=($ summation of three well plates for untreated cells $) \div 3$

No. of viable cells $(\%)=($ Average treated cell $\div$ average untreated cell $) \times 100 \%$

\subsection{Electrical Characterization}

The electrical responses of MCF7 and MCF10a cells were investigated by using an LCR meter (manufacture E4980) coupled with the interdigitated electrode (IDEs). The free-floating cells, with and without the GO treatment, in the suspension medium inside the plates, were first discarded before $5 \mu \mathrm{L}$ of the free-floating cells were deposited onto the IDE by using the drop cast method. The impedance and resistance changes before and after deposition were then monitored at a frequency between $20 \mathrm{~Hz}$ to $2 \mathrm{MHz}$.

\section{Results and Discussion}

\subsection{GO Characterization}

The obtained GO was first characterized by using the Raman spectroscopy, XRD spectroscopy, FESEM and EDX spectroscopy to confirm the morphology, structure and functional groups. The image obtained by using the 
Raman spectroscopy showed the presence of a characteristic graphitic D peak at $1367 \mathrm{~cm}^{-1}$ (as shown in Fig. 1). The peak may be produced by the disordered bands in $\mathrm{sp}^{2}$ hybridized carbon materials and led to the disruption of the symmetrical hexagonal graphitic lattice as a result of edge defects, internal structural defects and dangling bonds (Tan et al., 2013). Meanwhile, the $\mathrm{G}$ peak was centred at $1599 \mathrm{~cm}^{-1}$ and was referred to as the first order of the Raman band. This may be caused by all the $\mathrm{sp}^{2}$ hybridized carbon materials that was related to the C-C vibrational mode (Johra et al., 2014). The shift in the G band from $1582 \mathrm{~cm}^{-1}$ of graphite to $1599 \mathrm{~cm}^{-1}$ of GO was due to the presence of isolated double bonds on the GO carbon network (Tan et al., 2013). The other band, known as the 2D band, was observed at $2703 \mathrm{~cm}^{-1}$. The broadened 2D band peak was an indicator of the presence of GO layers (Johra et al., 2014).

\section{Fig. 1}

The XRD was used to characterize the crystalline materials in GO. By referring to (Johra et al., 2014), the XRD pattern in Fig. 2 is determined to be the crystalline natures of graphite and GO. Graphite exhibited a sharp peak at $2 \Theta=26.73$ degrees with d-spacing at $3.33 \AA$. After the oxidation of graphite, the sharp reflection peak shifted to the lower angle at $2 \Theta=11.54$ degrees with d-spacing at $7.67 \AA$, due to the formation of oxygen functional groups and the intercalation of water molecules into the carbon layer structure (Loryuenyong et al., 2013).

Fig. 2

For this observation, FESEM was operated at a very low voltage and at a constant working distance of 4.9 mm to produce the optimal imaging conditions. The observation analysis of Fig. 3 showed that the GO a very thin monolayer or few-layered structures made up of folded and wrinkled graphene films. The films were thin due to the mechanical forces produced by using an ultrasonication bath. The films were wrinkled, folded and stacked by a few layers of graphene due to the strong $\pi-\pi$ interaction at the surfaces (Muda et al., 2015). However, functional groups, such as the hydroxyl groups, were bonded to the basal plane of graphene sheets, therefore might disrupt the original conjugation and introduce the lattice defects as the folding and distortion on the graphene sheets (Johra et al., 2014).

Fig. 3

The EDX was used to investigate the elemental and quantitative compositions of the materials. In this research, an accelerating voltage of $20 \mathrm{kV}$ was used with a scan time of $100 \mathrm{~s}$ per sampling area. The EDX spectrum of GO is as shown in Fig. 4. The observation revealed the presence of Carbon (C), Oxygen (O) and Silicon (Si). The $\mathrm{C}$ content of the GO was valued at $45.58 \%$ and was obviously the highest as graphite is a carbon material. This was followed by $35.59 \%$ of $\mathrm{O}$ content due to the oxygen-containing functional groups produced from the oxidation process 
by using Hummer's method. The mass ratio of O/C was 0.78 . Finally, the Si content (18.83\%) was also present as substrates.

Fig. 4

\subsection{Cell Viability \& pH of GO}

One of the components that can be taken into consideration when maintaining the solubility of GO is the $\mathrm{pH}$ of the prepared GO. According to (X. Wang et al., 2011) and (Shih et al., 2012), the carboxyl groups of GO at lower $\mathrm{PH}$ are protonated, thus making the GO less hydrophilic, while at the higher $\mathrm{pH}$ of GO, the carboxyl groups are deprotonated, eventually enhance the hydrophilic features and resulting in better GO solubility. The cells membranes are semi-permeable and allow selected molecules to pass through the barriers and induce changes to the biological interactions. Therefore, to distinguish the interaction, an observation on the effect of different $\mathrm{pH}$ of GO towards the cell viability was done. Fig. 5 shows the numbers of viable MCF7 and MCF10a cells against the pH of GO after 24 hours (as shown in Fig. 5(a)) and 48 hours (as shown in Fig. 5(b)) incubation. After 24 hours of incubation (i.e. incubation period) for MCF10a (Fig. 5(a)), the percentage number of viable cells decreased to $90.5 \%, 92.8 \%$ and 98.4\% after the GO treatments with the $\mathrm{pH} \mathrm{5,6}$ and 7, respectively. Meanwhile, after 48 hours of incubation, the cell viability increased significantly to $109.8 \%, 113.6 \%$ and $116.4 \%$, respectively at the $\mathrm{pH} 5,6$ and 7 , as compared to after 24 hours incubation. These findings were somehow related to the findings of (X. Wang et al., 2011) and (Shih et al., 2012), which supported that the hydrophilic features were higher in the GO with $\mathrm{pH} 7$, as compared to the pH 5, due to the deprotonated carboxyl groups that occur at higher $\mathrm{pH}$ value.

As shown in Fig. 5(a), the percentages of viable MCF7 cells treated with different GO pH for 24 hours was relatively similar and were approximately $73.13 \%, 73.53 \%$ and $73.93 \%$, respectively. However, when the incubation period was increased to 48 hours (as shown in Fig. 5(b)), the percentages of viable MCF7 cells treated with different GO pH of 5, 6 and 7 dropped further to $63.07 \%, 58.93 \%$ and $56.98 \%$, respectively. These continuous decreases with respect to the incubation time somehow only occurred for the MCF7 compared to the MCF10a. These findings showed an increasing trend of cell viability for a longer incubation period. Moreover, the GO of $\mathrm{pH} 7$ had a greater effect on the cell viability, than the $\mathrm{GO}$ of $\mathrm{pH} 5$, and this corresponded to the hydrophilic properties. As the $\mathrm{pH}$ increased, the hydrophilicity of GO also increased. Hence, the prepared GO resulted in better solubility for better interactions with 
the cells. Therefore, for the next dose-dependent cell viability study, the GO of pH 7 was selected to be tested with varying GO concentrations, as the GO of $\mathrm{pH} 7$ was showed to inhibit the growth of breast cancer MCF7 cells while maintaining or increasing the viability of normal breast MCF10a cells.

Fig. 5

For the dose-dependent cell viability study, the GO concentrations were varied into six different concentrations (i.e. $2.5,6.25,12.5,25,50$ and $100 \mu \mathrm{g} / \mathrm{ml}$ ) while the $\mathrm{pH}$ of $\mathrm{GO}$ was fixed at 7 . Fig. 6 shows the comparison between the number of viable MCF10a and MCF7 cells against the different concentrations after 24 hours incubation time. The graph in Fig. 6 (a) shows a small percentage difference between the number of untreated and treated MCF10a cells. The average number of MCF10a cells varied between $1 \%$ to $7.89 \%$, as compared to the untreated MCF10a cells. Here, the value larger than $100 \%$ was inferred to the activation of MCF10a. In the case of 48 hours incubation period, the results, as in Fig. 6 (b), showed that the percentages of viable MCF10a were much larger (ca. $43.47 \%$ to $60.6 \%$ ), as compared to the untreated MCF10a cells. At the higher concentrations of GO (>25 $\mu \mathrm{g} / \mathrm{mL}$ ), the percentages of viable MCF10a cells were slightly larger than that of the lower GO concentrations. This increased resembled a much higher activation of MCF10a cells. Overall, the MCF10a activation does not have a strong dependency on the GO concentrations but rather is dependentt on the incubation time.

In the case of GO incubation with the MCF7 cells, the data in Fig. 6 (a) showed slight proportional to the GO concentrations of less than $25 \mu \mathrm{g} / \mathrm{ml}$, then showed inversely proportional relation appeared for the concentrations of more than $25 \mu \mathrm{g} / \mathrm{ml}$. Moreover, at $12.5 \mu \mathrm{g} / \mathrm{ml}$, the number of viable cells was larger than $100 \%$, thus indicated the activation of cells. The results were insignificant by considering the $10 \%$ error bar. However, the GO concentrations of less than $25 \mu \mathrm{g} / \mathrm{ml}$ are not sufficient to increase the inhibition rate, similar to the study for GO nanoflakes reacting with the MCF7 cells (Chang et al., 2011).

After the 48 hours incubation period, a similar trend of data was observed. However, the difference between the number of viable MCF7 and MCF10a cells was much larger at the higher GO concentration. For example, at the GO concentration of $100 \mu \mathrm{g} / \mathrm{ml}$, the difference was ca. $30 \%$ for the 24 hours incubation period, while it was $90 \%$ for that 48 hours, hence was proportional to the incubation time. This relation showed that the presence of GO was able to lower the activation rate of MCF7, as compared to the MCF10a.

Fig. 6 


\subsection{Electrical Responses Characterization}

\subsubsection{The electrical impedance and resistance responses of untreated and treated MCF7 and MCF10a cells with different pH of GO after 24 hours.}

The MCF7 and MCF10a cells, untreated and treated with different GO pH for 24 and 48 hours, were characterized based on the electrical impedance and resistance values. The $10 \mu \mathrm{m}$-gaps gold interdigitated electrodes

on glass substrate with the initial resistance of $2.0 \times 10^{5} \Omega$ were used. Then, the constant value of 1 volt was supplied by the E4980 Precision LCR meter equipped with LabVIEW 2012 software, to obtain the impedance and resistance values.

Fig. 7 (a-b) shows the electrical impedance and phase values from the untreated and treated MCF7 and MCF10a cells with different GO pH for 24 hours. From the plot, the cells treated with GO of pH 5 showed the highest impedance value, while the cells treated with GO of pH 7 showed the lowest impedance value. For the MCF7 cells treated with $\mathrm{GO}$ of $\mathrm{pH} 5$, the impedance value was $315.25 \Omega,-44.58^{\circ}$ at the frequency of $5 \mathrm{kHz}$ and dropped to 220.45 $\Omega,-39.05^{\circ}$ after the GO treatment at the $\mathrm{pH}$ of 7 .

From the results shown in Fig 7 (c-d), the MCF10a cells treated with GO at the pH of 7 and at the frequency of $5 \mathrm{kHz}$ showed the highest impedance value of $291.52 \Omega$ with a phase of $-48.10^{\circ}$, while the MCF10a cells treated with $\mathrm{GO}$ at the $\mathrm{pH}$ of 5 and at the frequency of $5 \mathrm{kHz}$ showed the lowest impedance value of $230.58 \Omega$ with a phase of $-45.98^{\circ}$. Therefore, an increased in the impedance lead to an increased in the resistance, followed by a decreased in the cells capacitance.

Fig. 7

As stated by (Mamouni \& Yang, 2011), without the cells, the impedance of the system can only come from the very low electrode capacitance $\left(\mathrm{C}_{\mathrm{dl}}\right)$ and the solution resistance $\left(\mathrm{R}_{\text {sol }}\right)$. For the MCF7, the $\mathrm{R}_{\text {sol }}$ value was $2.49 \mathrm{k} \Omega$ with the $\mathrm{C}_{\mathrm{dl}}$ equals to $989 \mathrm{nF}$, while for the MCF10a, the $\mathrm{R}_{\text {sol }}$ value was $1.63 \mathrm{k} \Omega$ with the $\mathrm{C}_{\mathrm{s}}$ equals to $1420 \mathrm{nF}$. After dropping the cells onto the electrode surface, the impedance of the attached cells is modelled as the capacitance component $\left(\mathrm{C}_{\text {cell }}\right)$ and the resistance component $\left(\mathrm{R}_{\text {cell }}\right)$ (Mamouni \& Yang, 2011; Seidel et al., 2016).

Table 1 shows the resistance and capacitance of untreated and treated MCF7 and MCF10a with different GO $\mathrm{pH}$ for 24 hours. The $\mathrm{R}_{\text {cell }}$ and $\mathrm{C}_{\text {cell }}$ values for both the treated MCF7 and MCF10a cells were compared, and observed 
that the resistance $\left(\mathrm{R}_{\text {cell }}\right)$ of MCF7 cells was recorded at $3.85 \mathrm{k} \Omega$ with the $\mathrm{C}_{\text {cell }}$ equals to $267 \mathrm{nF}$ after the treatment with GO of $\mathrm{pH}$ 7. This value was lower as compared to the $\mathrm{R}_{\text {cell }}$ value after the treatment with $\mathrm{GO}$ of $\mathrm{pH}$, which was $5.37 \mathrm{k} \Omega$ with the $\mathrm{C}_{\text {cell }}$ equals to $235 \mathrm{nF}$. Meanwhile, the $\mathrm{R}_{\text {cell }}$ value of MCF10a after treatment with $\mathrm{GO}$ of $\mathrm{pH} 7 \mathrm{was}$ $6.40 \mathrm{k} \Omega$ with the $\mathrm{C}_{\text {cell }}$ equals to $267 \mathrm{nF}$ and was higher as compared to the $\mathrm{R}_{\text {cell }}$ value after the treatment with $\mathrm{GO}$ of $\mathrm{pH}$ 5. These results proved that the declined in the capacitance values was due to the increased number of highly insulating cell membranes of viable cells that contributed to the increasing impedance, as the capacitance was inversely related to the impedance (Ma et al., 2013; Mamouni \& Yang, 2011; Pandya et al., 2014; Seidel et al., 2016). Hence, as the impedance value increases, the resistance value also increases according to Equation (2), while the impedance value corresponds to the resistance value. For conclusion, as the impedance increases, the resistance also increases.

\section{Table 1}

\subsubsection{The electrical impedance and resistance responses of untreated and treated MCF7 and MCF10a cells with different pH of GO after 48 hours.}

The results of impedance (as shown in Fig. 7) and resistance (as shown in Table 1) were compared with the number of viable cells (as shown in Fig. 5). The findings demonstrated that the MCF7 breast cancer cells had higher cell viability and lower resistance value as the $\mathrm{pH}$ increased, while the MCF10a also showed a similar increasing trend in cell viability and resistance value as the $\mathrm{pH}$ increased. It has been verified by (Kang et al., 2012) that the smaller gaps between the cells and electrodes led to better sensitivity in the cells' electrical impedance signals and resistances.

Meanwhile, Fig. 8 shows the electrical impedance and phase of untreated and treated MCF7 and MCF10a with different $\mathrm{GO} \mathrm{pH}$ and a longer incubation period of 48 hours. The results revealed that the impedance decreased as the frequency increased, especially when the frequency was below $500 \mathrm{kHz}$, and it converged at the frequencies higher than $500 \mathrm{kHz}$. According to (Mamouni \& Yang, 2011), this condition was due to the frequency-dependent characteristics, as calculated according to Equation (1). For MCF7, the impedance decreased from 191.01 $\Omega,-59.97^{\circ}$ after the treatment with $\mathrm{GO}$ of $\mathrm{pH} 5$ to $162.30 \Omega,-55.14^{\circ}$ after the treatment with $\mathrm{GO}$ of $\mathrm{pH} 7$. Meanwhile, for MCF10a, the impedance increased from $131.39 \Omega$ with the phase of $-47.46^{\circ}$ after the treatment with $\mathrm{GO}$ of $\mathrm{pH} 5$ to $170.29 \Omega$ with the phase of $-57.70^{\circ}$ after the treatment with GO of $\mathrm{pH} 7$.

Fig. 8 
The $\mathrm{R}_{\text {cell }}$ and $\mathrm{C}_{\text {cell }}$ for both the treated MCF7 and MCF10a cells were compared, and the results are as tabulated in Table 2. The $\mathrm{R}_{\text {cell }}$ value for MCF7 cells was the lowest at $3.23 \mathrm{k} \Omega$, with the $\mathrm{C}_{\text {cell }}$ equals to $673 \mathrm{nF}$, while the $\mathrm{R}_{\text {cell }}$ value MCF10a was the highest at $3.59 \mathrm{k} \Omega$, with the $\mathrm{C}_{\text {cell }}$ equals to $847 \mathrm{nF}$, after the treatment with $\mathrm{GO}$ of $\mathrm{pH}$ 7. The result for the impedance (as shown in Fig. 9) and resistance (as shown in Table 2) were compared with the number of viable cells (as shown in Fig. 5). The findings deduced that the increased impedance and resistance corresponded to the decreased of the gap between the highly insulating cell membranes of viable cells with the electrode surface and the decreased capacitance (Anh-Nguyen et al., 2016).

Table 2

\subsubsection{The electrical impedance and resistance responses of untreated and treated MCF7 and MCF10a cells with different concentrations of GO after 24 hours.}

The dose-dependent GO effects on the MCF7 and MCF10a cells are shown in Fig. 9 (a-b). The findings showed that the impedance of MCF7 cells rose after treatment with $12.5 \mu \mathrm{g} / \mathrm{mL}$ of GO at the $\mathrm{pH}$ of 7 . However, the impedance of MCF7 cells decreased as the GO concentrations increased. At a frequency of $5 \mathrm{kHz}$, the electrical impedance of the MCF7 cells treated with $12.5 \mu \mathrm{g} / \mathrm{mL}$ of GO was $425.27 \Omega$ with a phase of $-44.78^{\circ}$, while for the MCF7 cells treated with $100 \mu \mathrm{g} / \mathrm{mL}$ of GO, the electrical impedance was $220.45 \Omega$ with a phase of $-39.05^{\circ}$. Meanwhile, as shown in Fig. 9 (c-d), the MCF10a cells treated with $25 \mu \mathrm{g} / \mathrm{mL}$ of GO showed the highest impedance value of $345.03 \Omega$ with a phase of $-34.13^{\circ}$, while the MCF10a cells treated with $2.5 \mu \mathrm{g} / \mathrm{mL}$ of GO showed the lowest impedance of $210.27 \Omega$ with a phase of $-62.83^{\circ}$ at $5 \mathrm{kHz}$.

Fig. 9

An increasing impedance value shows the increasing resistance of the cells. For the MCF7 treated with 12.5 $\mu \mathrm{g} / \mathrm{mL}$ of $\mathrm{GO}$, the highest resistance $\left(\mathrm{R}_{\text {cell }}\right)$ value was $7.73 \mathrm{k} \Omega$ with the $\mathrm{C}_{\text {cell }}$ equals to $256 \mathrm{nF}$. Meanwhile, for the MCF10a treated with $25 \mu \mathrm{g} / \mathrm{mL}$ of $\mathrm{GO}$, the highest resistance value was $6.62 \mathrm{k} \Omega$ with the $\mathrm{C}_{\text {cell }}$ equals to $225 \mathrm{nF}$. The resistance and capacitance results of MCF7 and MCF10a untreated and treated with different GO concentrations for 24 hours were summarized in Table 3.

The impedance and resistance results trends were correlated to the number of viable cells trend, as shown in Fig. 6 (a). The highest number of viable MCF7 cells was recorded after the treatment with $12.5 \mu \mathrm{g} / \mathrm{mL}$ of GO, while the lowest was recorded after the treatment with $100 \mu \mathrm{g} / \mathrm{mL}$ of GO. Meanwhile, the highest number of viable MCF10a 
was recorded after the treatment with $25 \mu \mathrm{g} / \mathrm{mL}$ of $\mathrm{GO}$, while the lowest was recorded after the treatment with 2.5 $\mu \mathrm{g} / \mathrm{mL}$ of GO. The trend was comparable to the findings reported by (Anh-Nguyen et al., 2016). The study observed that the impedance and resistance increased to correspond with the decreased gap between the highly insulating cell membranes of viable cells with the electrode surface; hence it was related to the decreased capacitance. When the capacitance decreased, the impedance value increased, similar to the resistance value.

Table 3

\subsubsection{The electrical impedance and resistance responses of untreated and treated MCF7 and MCF10a cells with different concentrations of GO after 48 hours.}

Fig. 10 shows the electrical impedance and phase of MCF7 and MCF10a untreated or treated with different GO concentrations, with a longer incubation period of 48 hours. At a frequency below $500 \mathrm{kHz}$, the impedance decreased as the frequency increased. In contrast, it intersected and became stable at frequencies higher than $500 \mathrm{kHz}$. According to (Mamouni \& Yang, 2011), this condition was due to the frequency-dependent characteristics, as calculated according to Equation (1). For the MCF7 treated with $100 \mu \mathrm{g} / \mathrm{mL}$ of GO, the lowest impedance was 162.30 $\Omega$, with the phase of $-55.68^{\circ}$, while the highest impedance was $189.24 \Omega$, with the phase of $-59.87^{\circ}$ at the frequency of $5 \mathrm{kHz}$. On the other hand, for the MCF10a, the impedance increased from $139.13 \Omega$ with the phase of $-48.82^{\circ}$ to $170.29 \Omega$ with the phase of $-57.70^{\circ}$ at $5 \mathrm{kHz}$ after treated with a higher GO concentration of $100 \mu \mathrm{g} / \mathrm{mL}$.

Fig. 10

Without the cells, the resistance $\left(\mathrm{R}_{\text {sol }}\right)$ value for MCF7 was $2.49 \mathrm{k} \Omega$, with the $\mathrm{C}_{\mathrm{dl}}$ equals to $989 \mathrm{nF}$, while the $\mathrm{R}_{\text {sol }}$ for MCF10a was $1.63 \mathrm{k} \Omega$, with the $\mathrm{C}_{\mathrm{s}}$ equals to $1420 \mathrm{nF}$. With the cells on the electrode surface, the equivalent circuit contains the impedance contributed from the cells, in addition to the $\mathrm{R}_{\mathrm{sol}}$. The impedance of the attached cells was modelled as the resistances of the component $\left(\mathrm{R}_{\mathrm{cell}}\right)$ and the capacitance of the component $\left(\mathrm{C}_{\mathrm{cell}}\right)(\mathrm{Mamouni} \&$ Yang, 2011; Seidel et al., 2016). Table 4 shows the resistance $\left(\mathrm{R}_{\text {cell }}\right)$ and capacitance $\left(\mathrm{C}_{\text {cell }}\right)$ of MCF7 and MCF10a before and after incubation treatment with different GO concentrations for 48 hours. For the MCF7, the lowest $\mathrm{R}_{\text {cell }}$ value was $3.23 \mathrm{k} \Omega$, with the $\mathrm{C}_{\text {cell }}$ equals to $673 \mathrm{nF}$ after treatment with $100 \mu \mathrm{g} / \mathrm{mL}$ of $\mathrm{GO}$, while the highest $\mathrm{R}_{\text {cell }}$ value was $3.68 \mathrm{k} \Omega$, with the $\mathrm{C}_{\text {cell }}$ equals to $563 \mathrm{nF}$ after treatment with $12.5 \mu \mathrm{g} / \mathrm{mL}$ of $\mathrm{GO}$.

Table 4 
The impedance and resistance trends of MCF7 were similar for 24 and 48 hours, as compared to the results presented in Fig. 8 and Table 3. Thus, the results proved that the impedance and resistance were increased linearly with an increasing amount of highly insulating viable cells membrane on the IDEs, subsequently led to a decreased in the capacitance. These findings were in agreement with the findings of (Mamouni \& Yang, 2011). Meanwhile, the $\mathrm{R}_{\text {cell }}$ increased steadily from $2.43 \mathrm{k} \Omega$ to $3.59 \mathrm{k} \Omega$, with the $\mathrm{C}_{\text {cell }}$ equals to $1143 \mathrm{nF}$ and $847 \mathrm{nF}$ for MCF10a after 100 $\mu \mathrm{g} / \mathrm{mL}$ of GO treatment. It showed that the resistance trend was correspondent to the impedance, as shown in Fig. 10, and was comparable with the trend for the number of viable MCF7 and MCF10a cells, as shown in Fig. 6(b).

\section{Conclusion}

For this research, a few layers of GO, with an average size of 0.56 to $0.96 \mu \mathrm{m}$ and an average thickness of 1.24 to $1.32 \mathrm{~nm}$, were successfully produced by using the Hummer's method. Then, the GO was further synthesized and characterized by using the Raman spectroscopy, XRD spectroscopy, FESEM and EDX spectroscopy. The cell viability for both the MCF7 and MCF10a before and after treatment with GO was successfully determined by using the PrestoBlue cell viability assay. After treating both the MCF7 and MCF10a cells with three different pH (e.g. pH 5, 6 and 7), it was that when the GO pH increased to 7, the number of MCF7 viable cells was decreased, while the number of MCF10a viable cells was maintained at 24 hours incubation time. Also, the number of MCF7 viable cells was further decreased with the increasing number of MCF10a viable cells at 48 hours incubation time. Hence, it can be deduced that the GO of $\mathrm{pH} 7$ was the most suitable $\mathrm{pH}$ to inhibit the MCF7 proliferation compared to $\mathrm{pH} 5$ and $\mathrm{pH}$ 6, with the optimum incubation period at 24 hours. In terms of the dose-dependent interaction between cells and GO, the concentration of GO was varied into six different concentrations (e.g. 2.5, 6.25, 12.5, 25, 50 and $100 \mu \mathrm{g} / \mathrm{mL}$ ). For the electrical characterization part, the electrical properties of MCF7 and MCF10a cells before and after exposures to GO were successfully demonstrated by using $10 \mu \mathrm{m}$-gaps gold interdigitated electrodes connected to E4980 Precision LCR meter, equipped with LabVIEW 2012 software. In conclusion, the trend showing the number of viable cells was comparable with the capacitance, impedance, and resistance results. Thus, it was proven that the capacitance reduction was due to the increased in highly insulating MCF7 and MCF10a cells membrane. When dropped on the electrode surface, the highly insulated cells membrane caused an increase in electrical impedance and resistance. In conclusion, the electrical characterization and cell viability analyses of breast cancer cells using the GO deposited on IDE were successful. 


\section{Acknowledgements}

The authors would like to acknowledge the supports from the Fundamental Research Grant (FRGS) under a grant numbers of FRGS/1/2017/STG04/UNIMAP/02/1 and (FRGS/1/2018/STG07/UPM/02/6) given by the Ministry of Higher Education, Malaysia. 


\section{Reference}

Anh-Nguyen, T., Tiberius, B., Pliquett, U., \& Urban, G. A. (2016). An impedance biosensor for monitoring cancer cell attachment, spreading and drug-induced apoptosis. Sensors and Actuators, A: Physical, 241, 231-237. https://doi.org/10.1016/j.sna.2016.02.035

Barahuie, F., Saifullah, B., Dorniani, D., Fakurazi, S., Karthivashan, G., Hussein, M. Z., \& Elfghi, F. M. (2017). Graphene oxide as a nanocarrier for controlled release and targeted delivery of an anticancer active agent, chlorogenic acid. Materials Science and Engineering: C, 74, 177-185. https://doi.org/10.1016/j.msec.2016.11.114

Chang, Y., Yang, S. T., Liu, J. H., Dong, E., Wang, Y., Cao, A., Liu, Y., \& Wang, H. (2011). In vitro toxicity evaluation of graphene oxide on A549 cells. Toxicology Letters, 200(3), 201-210. https://doi.org/10.1016/j.toxlet.2010.11.016

Das, R. D., Mondal, N., Das, S., \& Roychaudhuri, C. (2012). Optimized electrode geometry for an improved impedance based macroporous silicon bacteria detector. IEEE Sensors Journal, 12(6), 1868-1877. https://doi.org/10.1109/JSEN.2011.2175724

Fu, P. P., Xia, Q., Hwang, H. M., Ray, P. C., \& Yu, H. (2014). Mechanisms of nanotoxicity: Generation of reactive oxygen species. In Journal of Food and Drug Analysis (Vol. 22, Issue 1, pp. 64-75). Elsevier Taiwan LLC. https://doi.org/10.1016/j.jfda.2014.01.005

Gurunathan, S., Han, J. W., Eppakayala, V., \& Kim, J. H. (2013). Green synthesis of graphene and its cytotoxic effects in human breast cancer cells. International Journal of Nanomedicine, 8, 1015-1027. https://doi.org/10.2147/IJN.S42047

Johra, F. T., Lee, J. W., \& Jung, W. G. (2014). Facile and safe graphene preparation on solution based platform. Journal of Industrial and Engineering Chemistry, 20(5), 2883-2887. https://doi.org/10.1016/j.jiec.2013.11.022

Kakran, M., G. Sahoo, N., Bao, H., Pan, Y., \& Li, L. (2011). Functionalized Graphene Oxide as Nanocarrier for Loading and Delivery of Ellagic Acid. Current Medicinal Chemistry, 18(29), 4503-4512. https://doi.org/10.2174/092986711797287548

Kang, G., Yoo, S. K., Kim, H. I., \& Lee, J. H. (2012). Differentiation between normal and cancerous cells at the single cell level using 3-D electrode electrical impedance spectroscopy. IEEE Sensors Journal, 12(5), 10841089. https://doi.org/10.1109/JSEN.2011.2167227

Loryuenyong, V., Totepvimarn, K., Eimburanapravat, P., Boonchompoo, W., \& Buasri, A. (2013). Preparation and characterization of reduced graphene oxide sheets via water-based exfoliation and reduction methods. Advances in Materials Science and Engineering, 2013. https://doi.org/10.1155/2013/923403

Ma, H., Wallbank, R. W. R., Chaji, R., Li, J., Suzuki, Y., Jiggins, C., \& Nathan, A. (2013). An impedance-based integrated biosensor for suspended DNA characterization. Scientific Reports, 3. https://doi.org/10.1038/srep02730

Mamouni, J., \& Yang, L. (2011). Interdigitated microelectrode-based microchip for electrical impedance spectroscopic study of oral cancer cells. Biomedical Microdevices, 13(6), 1075-1088. https://doi.org/10.1007/s10544-011-9577-8

Muda, M. R., Hanim, K. N., Mat Isa, S. S., Ramli, M. M., \& Jamlos, M. F. (2015). High Throughput Graphene Oxide in Modified Hummers Method and Annealing Effect on Different Deposition Method. Applied Mechanics and Materials, 815, 141-147. https://doi.org/10.4028/www.scientific.net/amm.815.141

Muda, M. R., Ramli, M. M., Isa, S. S. M., Jamlos, M. F., Murad, S. A. Z., Norhanisah, Z., Isa, M. M., Kasjoo, S. R., Ahmad, N., Nor, N. I. M., \& Khalid, N. (2017). Fundamental study of reduction graphene oxide by sodium borohydride for gas sensor application. AIP Conference Proceedings, 1808(1), 020034. 
https://doi.org/10.1063/1.4975267

Pandya, H. J., Kim, H. T., Roy, R., Chen, W., Cong, L., Zhong, H., Foran, D. J., \& Desai, J. P. (2014). Towards an automated MEMS-based characterization of benign and cancerous breast tissue using bioimpedance measurements. Sensors and Actuators, B: Chemical, 199, 259-268. https://doi.org/10.1016/j.snb.2014.03.065

Saeed, L. M., Mahmood, M., Pyrek, S. J., Fahmi, T., Xu, Y., Mustafa, T., Nima, Z. A., Bratton, S. M., Casciano, D., Dervishi, E., Radominska-Pandya, A., \& Biris, A. S. (2014a). Single-walled carbon nanotube and graphene nanodelivery of gambogic acid increases its cytotoxicity in breast and pancreatic cancer cells. Journal of Applied Toxicology : JAT, 34(11), 1188-1199. https://doi.org/10.1002/jat.3018

Saeed, L. M., Mahmood, M., Pyrek, S. J., Fahmi, T., Xu, Y., Mustafa, T., Nima, Z. A., Bratton, S. M., Casciano, D., Dervishi, E., Radominska-Pandya, A., \& Biris, A. S. (2014b). Single-walled carbon nanotube and graphene nanodelivery of gambogic acid increases its cytotoxicity in breast and pancreatic cancer cells. Journal of Applied Toxicology, 34(11), 1188-1199. https://doi.org/10.1002/jat.3018

Seidel, D., Obendorf, J., Englich, B., Jahnke, H. G., Semkova, V., Haupt, S., Girard, M., Peschanski, M., Brüstle, O., \& Robitzki, A. A. (2016). Impedimetric real-time monitoring of neural pluripotent stem cell differentiation process on microelectrode arrays. Biosensors and Bioelectronics, 86, 277-286. https://doi.org/10.1016/j.bios.2016.06.056

Shih, C. J., Lin, S., Sharma, R., Strano, M. S., \& Blankschtein, D. (2012). Understanding the pH-dependent behavior of graphene oxide aqueous solutions: A comparative experimental and molecular dynamics simulation study. Langmuir, 28(1), 235-241. https://doi.org/10.1021/la203607w

Tan, L. L., Ong, W. J., Chai, S. P., \& Mohamed, A. R. (2013). Reduced graphene oxide-TiO2 nanocomposite as a promising visible-light-active photocatalyst for the conversion of carbon dioxide. Nanoscale Research Letters, 8(1). https://doi.org/10.1186/1556-276X-8-465

Wang, L., Veselinovic, M., Yang, L., Geiss, B. J., Dandy, D. S., \& Chen, T. (2017). A sensitive DNA capacitive biosensor using interdigitated electrodes. Biosensors and Bioelectronics, 87, 646-653. https://doi.org/10.1016/j.bios.2016.09.006

Wang, X., Bai, H., \& Shi, G. (2011). Size fractionation of graphene oxide sheets by $\mathrm{pH}$-assisted selective sedimentation. Journal of the American Chemical Society, 133(16), 6338-6342. https://doi.org/10.1021/ja200218y

Wu, J., Yang, R., Zhang, L., Fan, Z., \& Liu, S. (2015). Cytotoxicity effect of graphene oxide on human MDA-MB231 cells. Toxicology Mechanisms and Methods, 25(4), 312-319. https://doi.org/10.3109/15376516.2015.1031415

Zhang, B., Wei, P., Zhou, Z., \& Wei, T. (2016). Interactions of graphene with mammalian cells: Molecular mechanisms and biomedical insights. In Advanced Drug Delivery Reviews (Vol. 105, pp. 145-162). Elsevier B.V. https://doi.org/10.1016/j.addr.2016.08.009 
Figures:

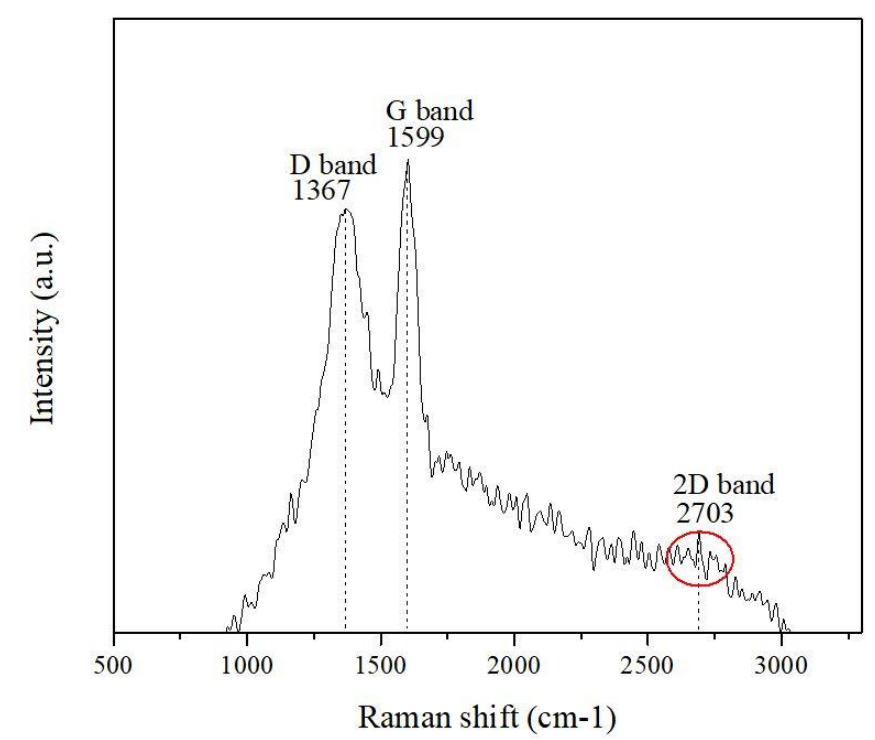

Fig 1. Raman spectrum of GO.

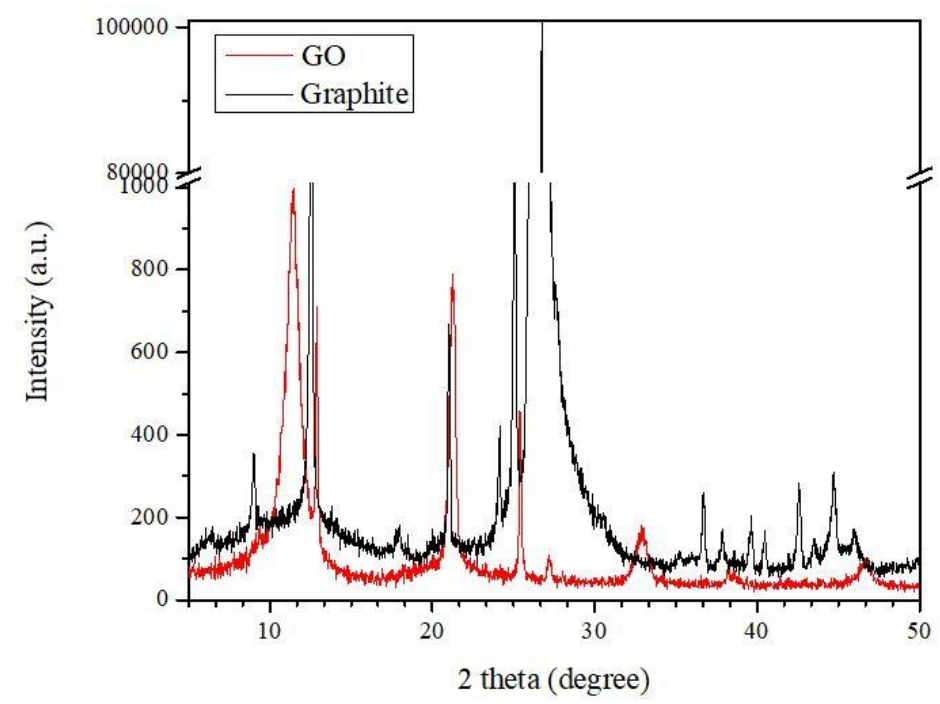

Fig 2. XRD patterns of graphite and GO deposited on Si. 


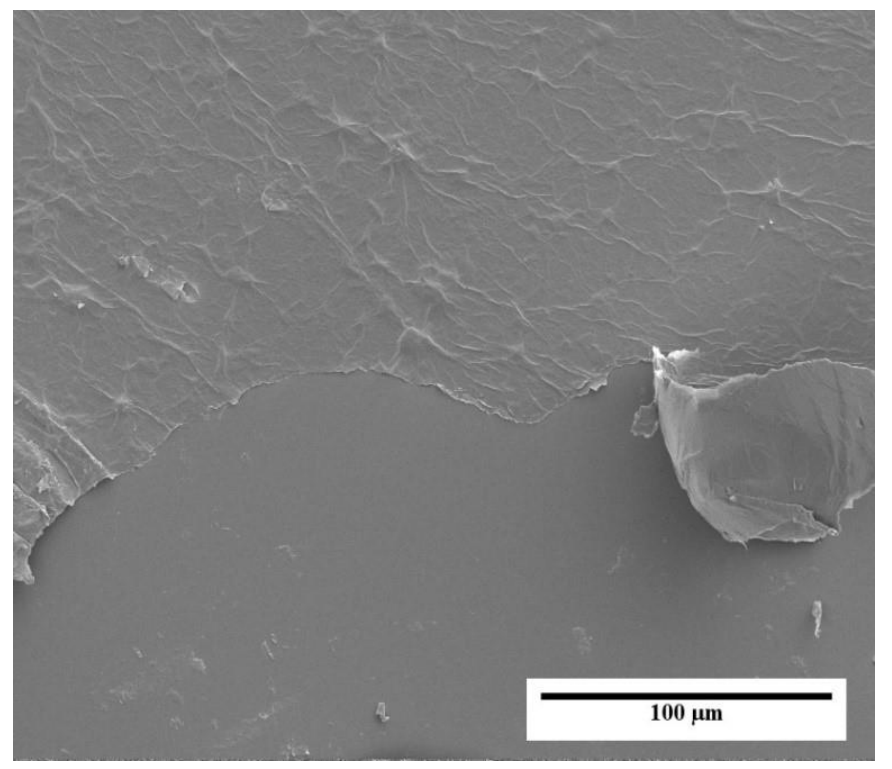

Fig 3. FESEM of GO sheet deposited on Si.

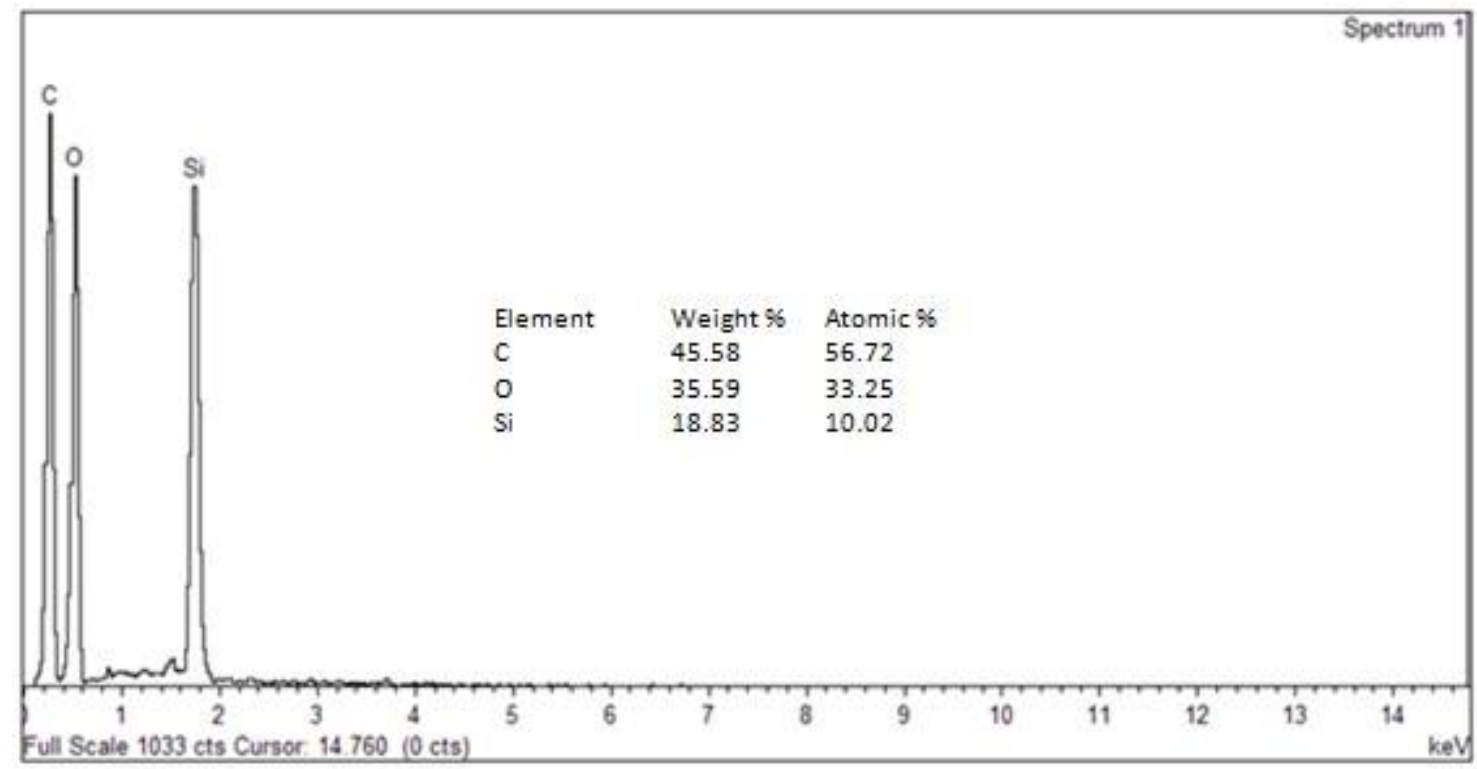

Fig 4. EDX spectra of GO deposited on Si. 
(a)

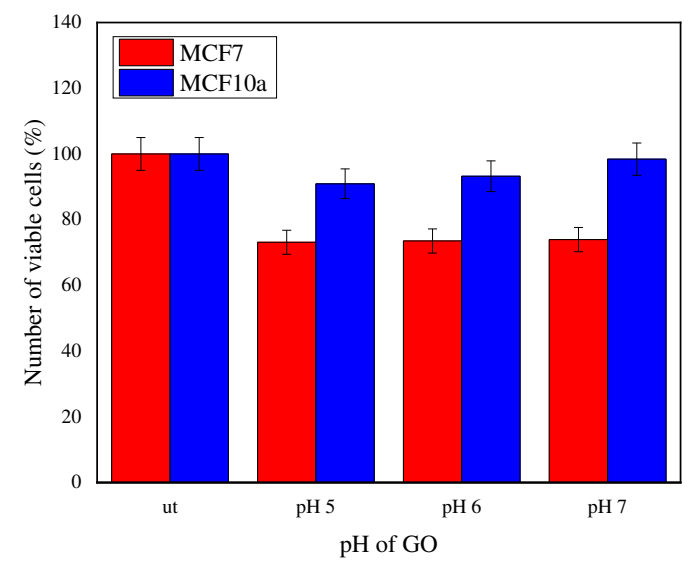

(b)

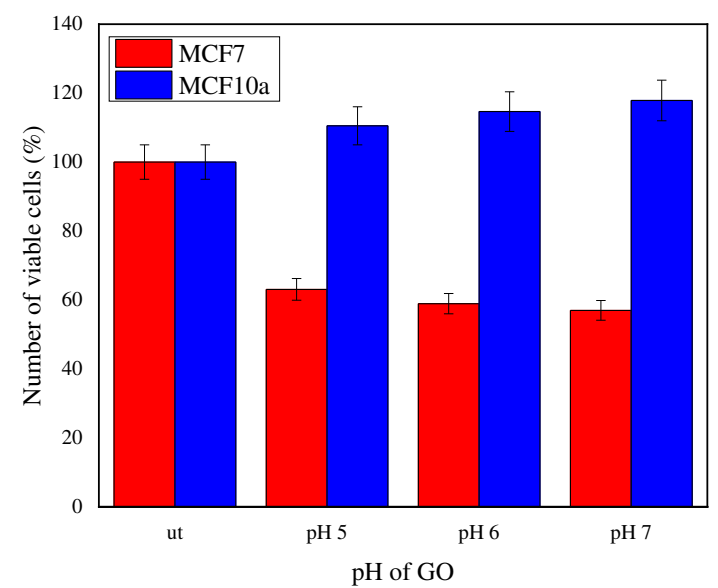

Figure 5. The comparison between number of viable cells of MCF7 and MCF10a against pH of GO after (a) 24 hours (b) 48 hours. The ut represents the untreated cells or cells which was not treated with GO.

(a)

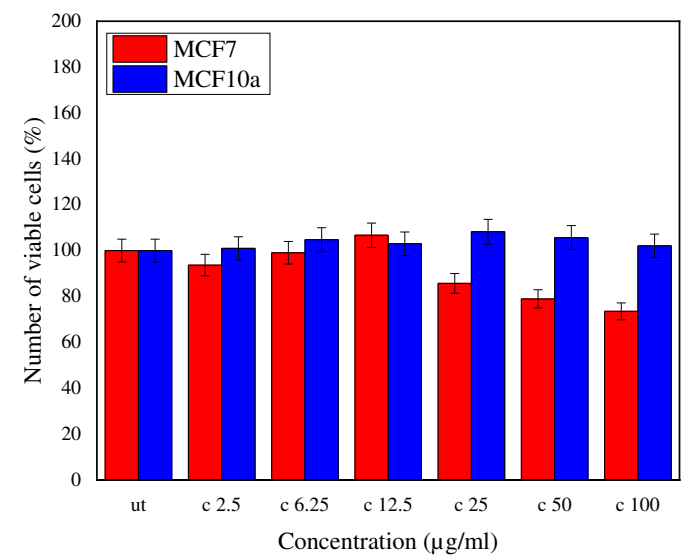

(b)

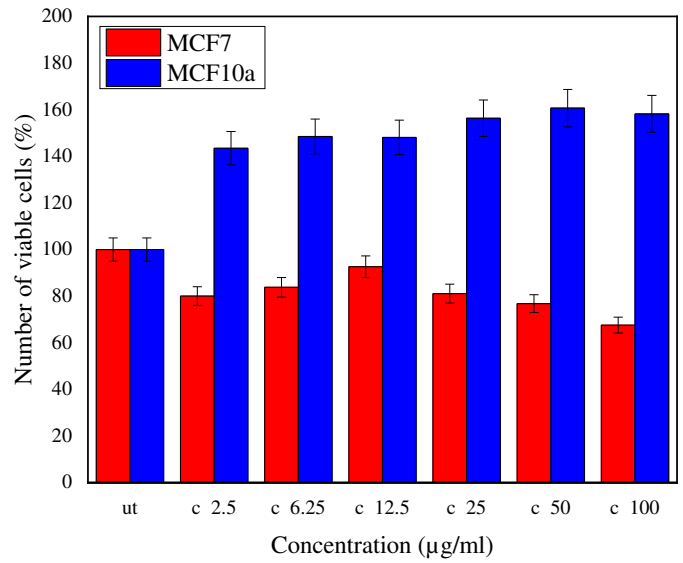

Figure 6. The comparison between number of viable cells of MCF7 and MCF10a against concentration of GO after (a) 24 hours and (b) 48 hours. The ut represents the untreated cells or cells which was not treated with GO. 
(a)

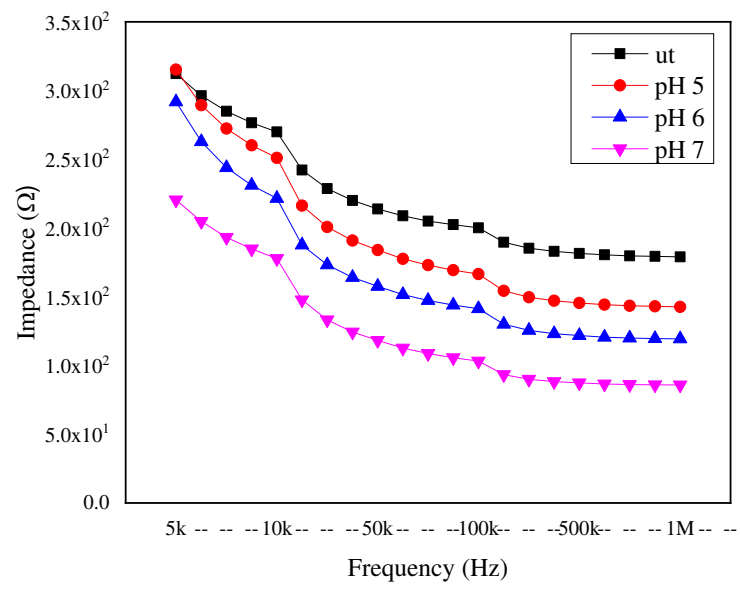

(c)

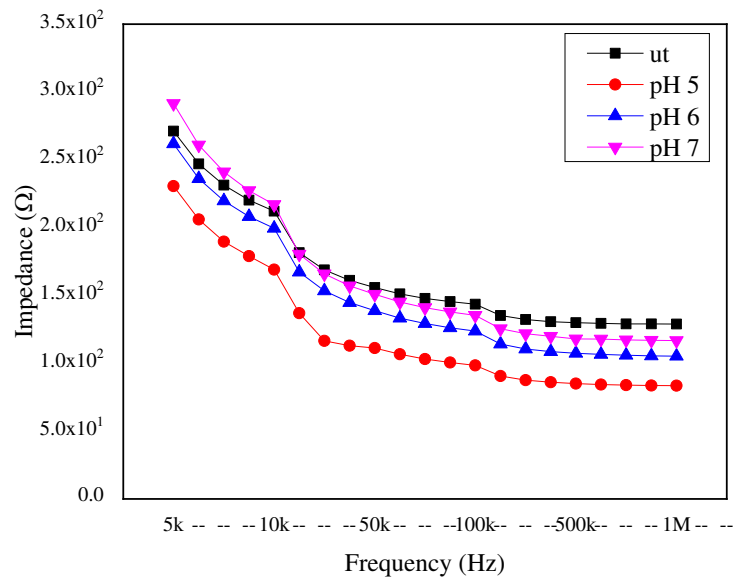

(b)

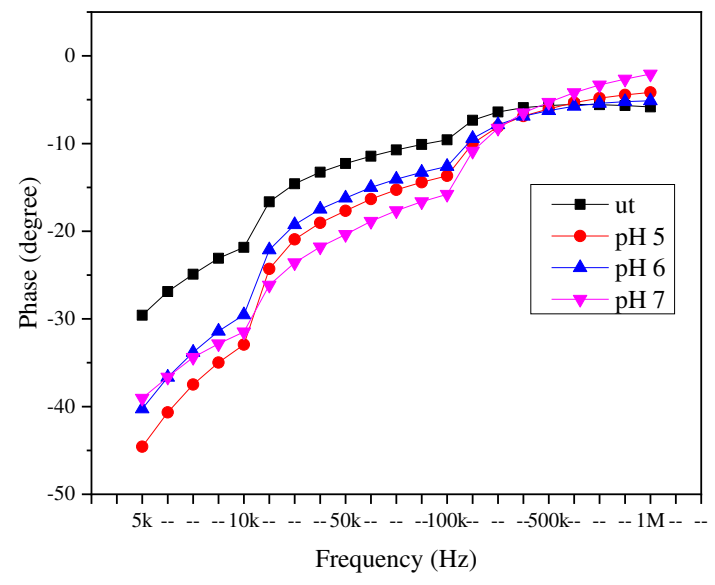

(d)

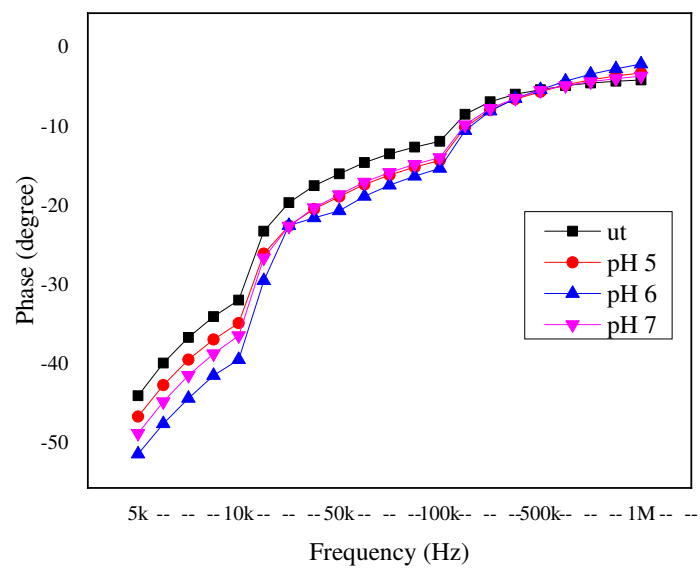

Figure 7. The electrical (a) impedance and (b) phase of untreated and treated breast cancer cell (MCF7) and the electrical (c) impedance and (d) phase of untreated and treated normal breast cell (MCF10a) with different pH of GO for 24 hours. 
Table 1. The resistance and capacitance of MCF7 and MCF10a before and after treated with different $\mathrm{pH}$ of GO for 24 hours incubation time.ut: Untreated cells or cells which was not treated with GO

\begin{tabular}{ccccc}
\hline \multirow{2}{*}{$\begin{array}{c}\text { MH of } \\
\text { GO }\end{array}$} & $\begin{array}{c}\text { Resistance of } \\
\text { component, } \mathrm{R}_{\text {cell }}(\Omega)\end{array}$ & $\begin{array}{c}\text { Capacitance of } \\
\text { component, } \mathrm{C}_{\text {cell }}(\mathrm{nF})\end{array}$ & $\begin{array}{c}\text { Resistance of } \\
\text { component, } \mathrm{R}_{\text {cell }}(\Omega)\end{array}$ & $\begin{array}{c}\text { Capacitance of } \\
\text { component, } \mathrm{C}_{\text {cell }}(\mathrm{nF})\end{array}$ \\
\cline { 2 - 5 } ut & 4732.90 & 775.0 & 2467.20 & 710.0 \\
$\mathrm{pH} \mathrm{5}$ & 5370.97 & 235.0 & 4819.82 & 330.0 \\
$\mathrm{pH} \mathrm{6}$ & 4818.53 & 276.0 & 5010.24 & 329.0 \\
$\mathrm{pH} \mathrm{7}$ & 3857.77 & 814.0 & 6398.32 & 267.0 \\
\hline
\end{tabular}

(a)

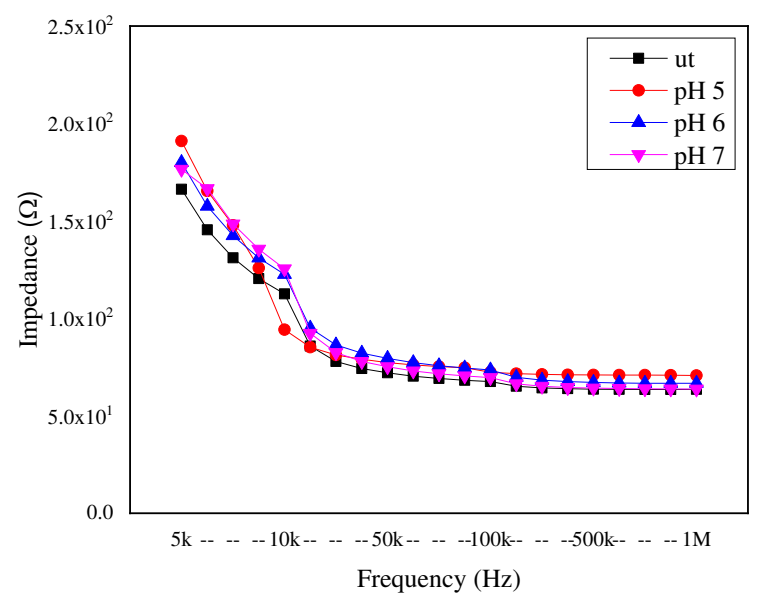

(b)

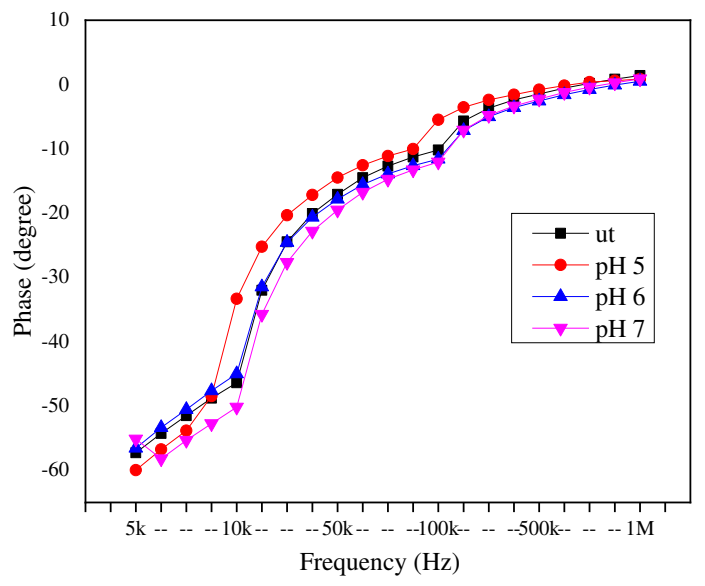


(c)

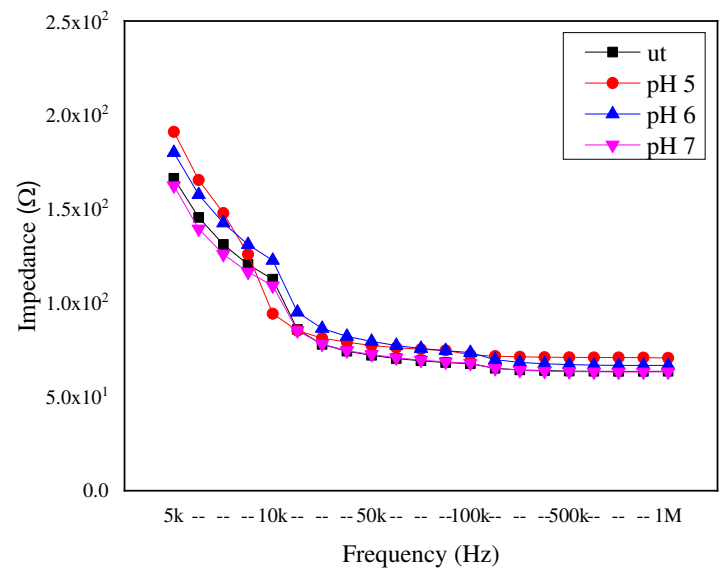

(d)

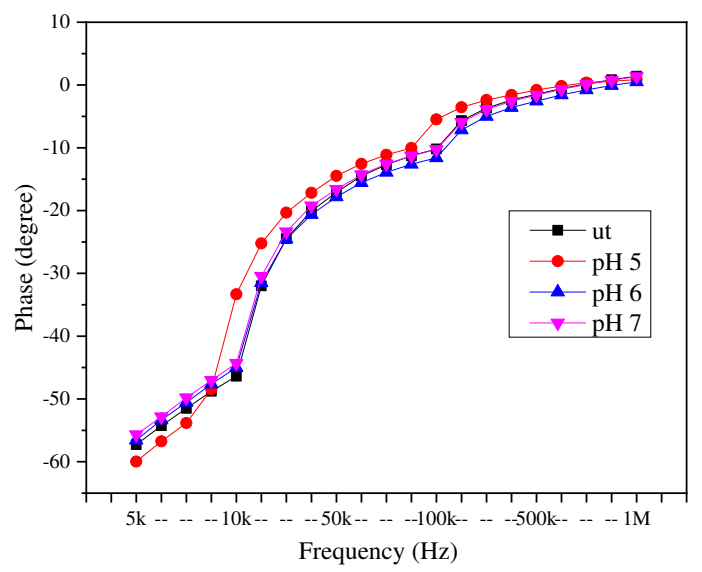

Figure 8. The electrical (a) impedance and (b) phase of untreated and treated breast cancer cell (MCF7) and the (c) impedance and (d) phase of untreated and treated normal breast cell (MCF10a) with different pH of GO for 48 hours.

Table 2. The resistance and capacitance of MCF7 and MCF10a before and after treated with different $\mathrm{pH}$ of GO for 48 hours incubation time.

\begin{tabular}{ccccc}
\hline \multirow{2}{*}{$\begin{array}{c}\text { MH of } \\
\text { GO }\end{array}$} & $\begin{array}{c}\text { Resistance of } \\
\text { component, } \mathrm{R}_{\text {cell }}(\Omega)\end{array}$ & $\begin{array}{c}\text { Capacitance of } \\
\text { component, } \mathrm{C}_{\text {cell }}(\mathrm{nF})\end{array}$ & $\begin{array}{c}\text { Resistance of } \\
\text { component, } \mathrm{R}_{\text {cell }}(\Omega)\end{array}$ & $\begin{array}{c}\text { MCF10a } \\
\text { component, } \mathrm{C}_{\text {cell }}(\mathrm{nF})\end{array}$ \\
\hline ut & 2944.70 & 1140.0 & 2427.30 & 1130.0 \\
pH 5 & 3319.37 & 463.0 & 2350.95 & 1240.0 \\
pH 6 & 3257.15 & 642.0 & 2454.77 & 1170.0 \\
pH 7 & 3226.02 & 673.0 & 3589.18 & 847.0 \\
\hline
\end{tabular}

ut: Untreated cells or cells which was not treated with GO 
(a)

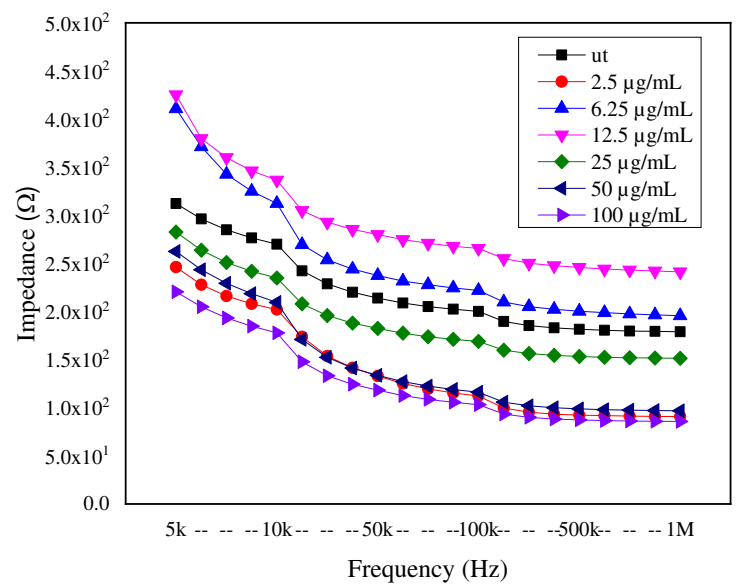

(c)

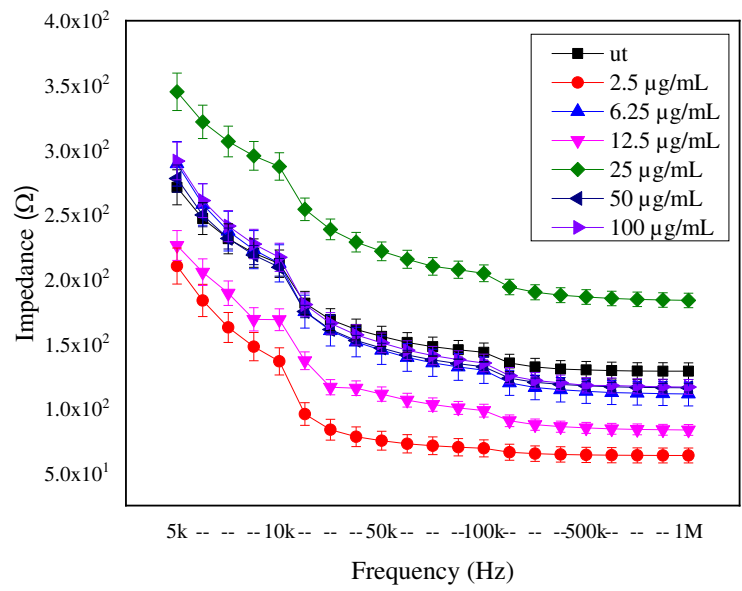

(b)

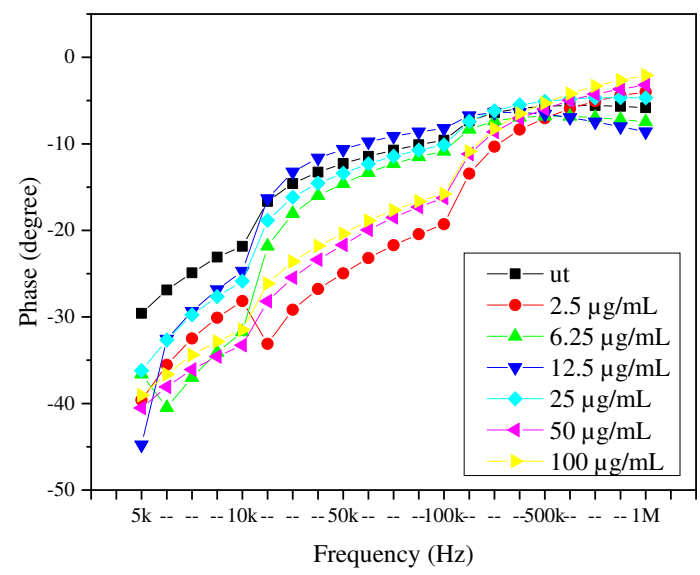

(d)

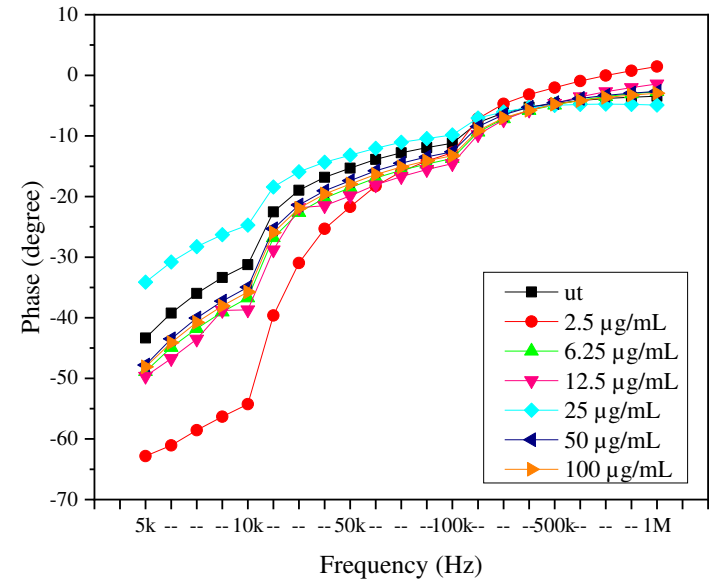

Figure 9. The electrical (a) impedance and (b) phase of untreated and treated breast cancer cell (MCF7) and the (c) impedance and (d) phase of untreated and treated normal breast cell (MCF10a) with different concentration of GO for 24 hours. 
Table 3. The resistance and capacitance of MCF7 and MCF10a before and after treated with different concentration of GO for 24 hours incubation time.

\begin{tabular}{|c|c|c|c|c|}
\hline \multirow[t]{2}{*}{ Concentration of GO } & \multicolumn{2}{|c|}{ MCF7 } & \multicolumn{2}{|c|}{ MCF10a } \\
\hline & $\begin{array}{c}\text { Resistance of } \\
\text { component, } \mathrm{R}_{\text {cell }}(\Omega)\end{array}$ & $\begin{array}{c}\text { Capacitance of } \\
\text { component, } \mathrm{C}_{\text {cell }}(\Omega)\end{array}$ & $\begin{array}{c}\text { Resistance of } \\
\text { component, } \mathrm{R}_{\text {cell }}(\Omega)\end{array}$ & $\begin{array}{c}\text { Capacitance of } \\
\text { component, } \mathrm{C}_{\text {cell }}(\Omega)\end{array}$ \\
\hline ut & 4732.90 & 775.0 & 2467.20 & 710.0 \\
\hline 2.5 & 4497.88 & 716.0 & 4819.82 & 935.0 \\
\hline 6.25 & 4818.53 & 276.0 & 6219.79 & 288.0 \\
\hline 12.5 & 7730.03 & 256.0 & 5078.66 & 687.0 \\
\hline 25 & 4451.92 & 589.0 & 6621.56 & 225.0 \\
\hline 50 & 3257.91 & 640.0 & 5835.85 & 261.0 \\
\hline 100 & 3857.77 & 814.0 & 6398.32 & 267.0 \\
\hline
\end{tabular}

ut: Untreated cells or cells which was not treated with GO 
(a)

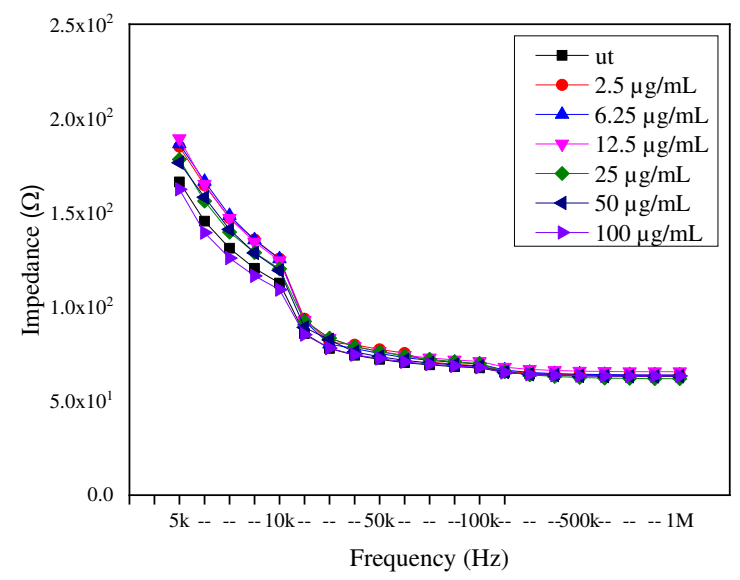

(c)

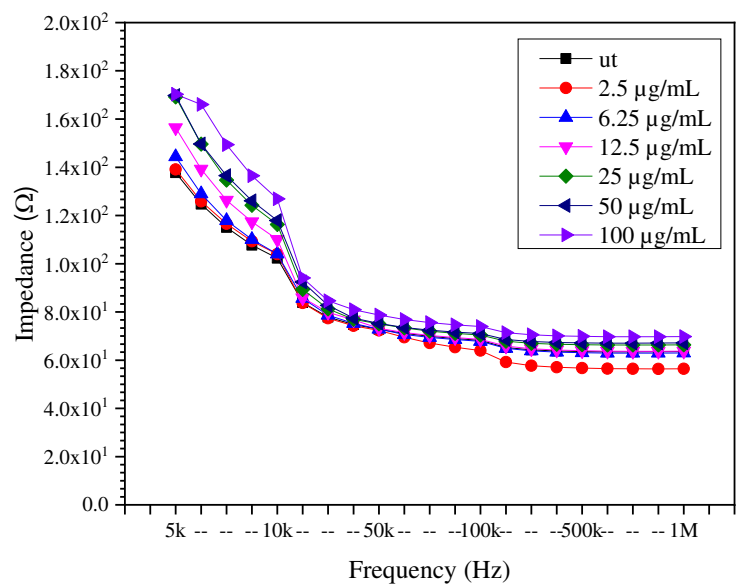

(b)

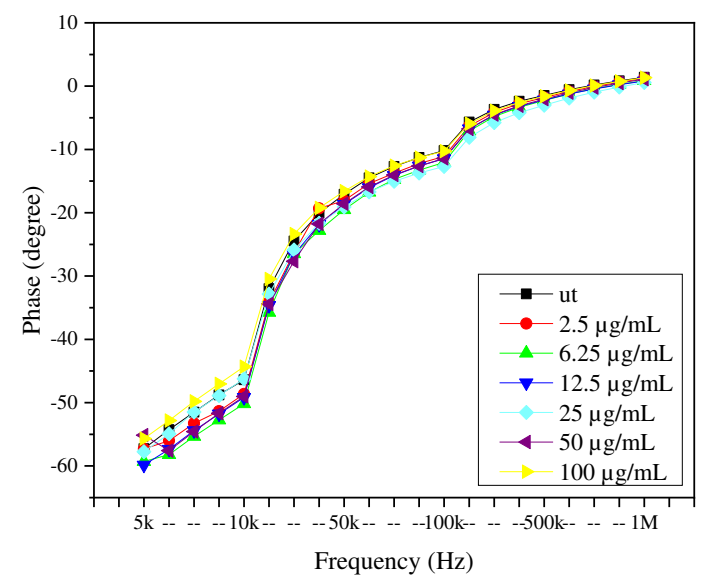

(d)

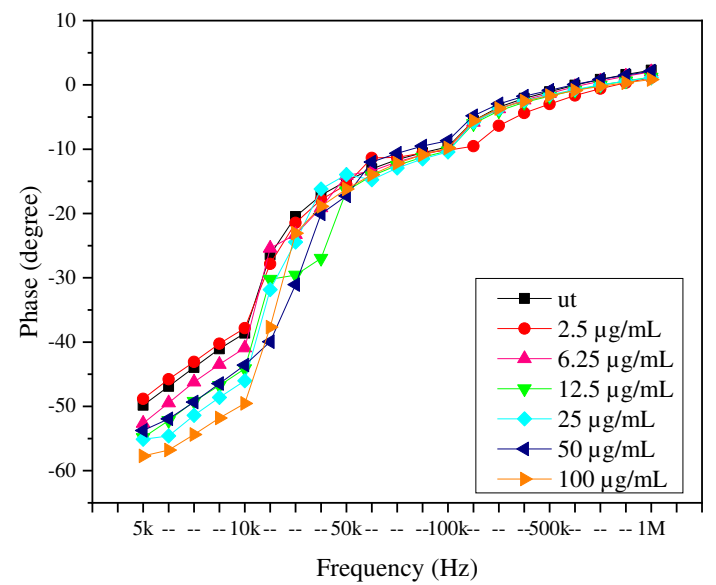

Figure 10. The electrical (a) impedance and (b) phase of untreated and treated breast cancer cell (MCF7) and the (c) impedance and (d) phase of untreated and treated normal breast cell (MCF10a) with different concentration of GO for 48 hours. 
Table 4. The resistance and capacitance of MCF7 and MCF10a before and after treated with different concentration of GO for 48 hours incubation time.

\begin{tabular}{|c|c|c|c|c|}
\hline \multirow{2}{*}{$\begin{array}{c}\text { Concentration of } \\
\text { GO }\end{array}$} & \multicolumn{2}{|c|}{ MCF7 } & \multicolumn{2}{|c|}{ MCF10a } \\
\hline & $\begin{array}{c}\text { Resistance of } \\
\text { component, } \mathrm{R}_{\text {cell }}(\Omega)\end{array}$ & $\begin{array}{c}\text { Capacitance of } \\
\text { component, } \mathrm{C}_{\text {cell }}(\mathrm{nF})\end{array}$ & $\begin{array}{c}\text { Resistance of } \\
\text { component, } \mathrm{R}_{\text {cell }}(\Omega)\end{array}$ & $\begin{array}{c}\text { Capacitance of } \\
\text { component, } \mathrm{C}_{\text {cell }}(\mathrm{nF})\end{array}$ \\
\hline Ut & 2944.70 & 1140.0 & 2427.30 & 1130.0 \\
\hline 2.5 & 3648.55 & 631.0 & 2433.77 & 1141.0 \\
\hline 6.25 & 3673.58 & 572.0 & 2509.06 & 1120.0 \\
\hline 12.5 & 3684.56 & 563.0 & 2969.99 & 951.0 \\
\hline 25 & 3486.65 & 601.0 & 2996.11 & 937.0 \\
\hline 50 & 3276.41 & 628.0 & 3415.25 & 884.0 \\
\hline 100 & 3226.02 & 673.0 & 3589.18 & 847.0 \\
\hline
\end{tabular}

ut: Untreated cells or cells which was not treated with GO 